\title{
Oxytocin induced oxidative stress in lactating Bubalis bubalis (Nili Ravi)
}

\author{
Zafar lqbal', Zia Ur Rahman², Faqir Muhammad ${ }^{3}$, Tanweer Khaliq ${ }^{3}$, Haseeb Anwar ${ }^{4}$, \\ Mian Muhammad Awais ${ }^{5}$ and Saima Sadaf $f^{6}$
}

\begin{abstract}
Background: Oxytocin has been reported for a wide range of adverse effects in different species of lactating animals. The present study was aimed to evaluate the adverse effects of oxytocin on biomarkers of oxidative stress in buffaloes. Lactating buffaloes $(n=40)$ were randomly selected from a commercial dairy farm located in the peri-urban area of district Faisalabad, Pakistan and divided into two equal groups viz. treatment and control groups, each containing 20 buffaloes. Buffaloes in treatment group were injected with oxytocin before each milking (morning and evening) for milk let down; whereas, animals in control group were milked naturally without oxytocin injection. Both the groups were assessed for oxidative stress biomarkers.

Results: Results showed significantly higher levels ( $P \leq 0.05$ ) of TOS, tHcy and ceruloplasmin oxidase activity in lactating buffaloes injected with oxytocin as compared to those of control group. On the other hand, serum levels of TAS, PON1 and arylesterase were significantly lower $(P \leq 0.05)$ in the buffaloes of treatment group.

Conclusions: Oxytocin injection in lactating buffaloes resulted in elevated oxidative stress by increasing the total homocysteine and ceruloplasmin oxidase activity and decreasing enzymatic activities of antioxidant enzymes including paraoxonase-1 and arylesterase; that might render the animals to poor productive and reproductive potential.
\end{abstract}

Keywords: Oxytocin, Oxidative stress, Biomarkers, Lactating buffaloes

\section{Background}

Buffaloes are said to be slow and hard milkers because of their slow milk ejection reflexes and hard teat sphincter muscles [1]. As a general practice, exogenous oxytocin injections are frequently administered in dairy animals to initiate the milk let down or occasionally to cure the disturbed milk ejection [2,3]. However, long term oxytocin administration in dairy animals could lead to addiction and reduced spontaneous milk ejection after withdrawal of oxytocin [4].

Total antioxidant capacity (TAC) provides biologically more relevant information that describes the dynamic equilibrium between pro-oxidants and antioxidants in the plasma compartment of animals and human beings [5]. Under physiological conditions, there are sufficient reserves of antioxidants in the body that has the capability to cope with the production of free radicals [6], which are produced continuously during normal metabolism and may increase

\footnotetext{
* Correspondence: drziar@yahoo.com

${ }^{2}$ Sub-Campus Toba Tek Singh, University of Agriculture, Faisalabad, Pakistan Full list of author information is available at the end of the article
}

as a result of pathological conditions [7]. However, when the production of free radicals exceeds the body's antioxidant production potential, oxidative stress develops [8]. In dairy animals, pre-partum and early post-partum periods are very critical as they prone the animals to considerable physiological challenges by imposing significant metabolic stressors that may contribute to the onset of diverse disorders including ketosis, milk fever, mineral deficiencies etc. [9]. In Pakistan, oxytocin is widely used in dairy animals to increase the milk production due to the lack of awareness about the health hazards associated with irrational use of oxytocin. Keeping in view, the present study was conducted to determine the effect of oxytocin injection on health/oxidative stress biomarkers of lactating buffaloes.

\section{Results}

Indicators of oxidative stress

Total oxidant status (TOS) and total antioxidant capacity (TAC) In oxytocin injected group, the serum TOS $(\mu \mathrm{Mol} / \mathrm{L})$ was significantly higher $(\mathrm{P} \leq 0.05)$ during 1 st $(0.97)$ and 5th month (0.98) of lactation as compared to control group 
(not injected with oxytocin). TAC (mMol/L) was significantly higher $(\mathrm{P} \leq 0.05)$ in control buffaloes on 2nd $(0.40)$, 3rd (1.06), 4th (0.78) and 6th months (0.55) of lactation as compared to oxytocin injected buffaloes; whereas, the highest value for TAC was recorded on 3rd month (1.06) of lactation in control group (Table 1). Pearson correlation coefficients indicated that TOS was positively correlated $(\mathrm{r}=$ 0.604) with TAC in the control buffaloes (Table 2); whereas, in treated buffaloes no such significance was detected.

\section{Total homocysteine (tHcy)}

A significantly higher $(\mathrm{P} \leq 0.05)$ concentration of tHcy $(\mu \mathrm{Mol} / \mathrm{L})$ was recorded in buffaloes of oxytocin injected group on 1st (16.77), 2nd (17.04) and 4th months (17.52) of lactation when compared with those of control group; whereas, highest tHcy concentration was detected on 4th month (17.52) of lactation (Table 1). Correlation analysis revealed a positive correlation of tHcy with TOS $(\mathrm{r}=0.481)$ and TAC $(\mathrm{r}=0.389$; Table 2$)$.

\section{Paraoxonase-1 (PON1) activity}

Buffaloes of control group showed significantly higher $(\mathrm{P} \leq 0.05)$ serum PON1 activity (U/L) during 2nd (58.29), 4th (51.41) and 5th months (46.98) of lactation as compared to those of oxytocin injected group which showed significantly higher PON1 activity during 1st month (45.74) of lactation (Table 1). PON1 activity of control group was positively correlated with TOS $(r=0.211)$, TAC $(r=0.209)$, ceruloplasmin oxidase activity $(r=0.184)$ and negatively correlated with arylesterase activity $(r=-0.379$; Table 2). PON1 activity of the lactating buffaloes injected with oxytocin showed a negative correlation with ceruloplasmin oxidase activity $(\mathrm{r}=-0.255)$.

\section{Arylesterase activity}

The serum arylesterase activity (U/L) increased significantly $(\mathrm{P} \leq 0.05)$ during 1st (47.12), 5th (40.74) and 6th months (52.06) of lactation and the highest level was observed during 6th month (52.06) in the control group (Table 1). Arylesterase activity of oxytocin injected group was positively correlated with TAC $(r=0.324)$ and ceruloplasmin oxidase activity $(\mathrm{r}=0.199)$.

\section{Ceruloplasmin oxidase activity}

Animals injected with oxytocin showed significantly higher $(\mathrm{P} \leq 0.05)$ ceruloplasmin oxidase activity $(\mathrm{U} / \mathrm{L})$ during 1 st (55.91) and 4th months (100.44) of lactation as compared to control group; whereas, on 3rd month of lactation the difference between the ceruloplasmin oxidase activity of both the groups was statistically similar $(P \geq 0.05)$ (Table 1$)$.

\section{Discussion}

Oxytocin has been reported for a wide range of adverse effects in lactating animals including sheep, goat, cattle and buffaloes [2-4]. In lactating animals, the start of lactation is an important event with respect to the production of free radical(s). It has been reported in the literature that in malnourished lactating animals, negative energy balance is developed and in such circumstances, oxytocin favors the production of free radicals through mobilization of stored lipids and gluconeogenesis $[10,11]$. Further, excessive oxidation of non-esterified fatty acids (NEFA) in the liver also increased the production of reactive oxygen species (ROS) which ultimately produced the oxidative stress [12].

In the present study, statistically TOS was higher and TAC was lower in oxytocin injected buffaloes and these results are consistent to the findings of [6] who conducted similar studies in lactating cows. This might be due to the depletion of fat soluble antioxidants by the milk $[8,13]$. Further, this reduction might also be due to decreased level of PON1 [14] that was another peculiar finding of this study. Moreover, in some previous studies, reduction in TAC just after calving had also been correlated with increased production of reactive oxygen metabolites (ROM) and thiobarbituric acid reactive substance. Elevation in these reactive substances induced imbalance between TAC and production of free radicals leading to lipid peroxidation [15].

Oxidative stress has an important role in the metabolism of homocysteine. In present study, significantly higher tHcy level was detected in oxytocin injected buffaloes that might be correlated with higher level of free radicals in circulation [16]. Similarly, [10] also observed a significant increase in the serum homocysteine on day 200 of lactation in the lactating ewes. Altered plasma homocysteine levels had also been correlated with certain dietary factors such as protein and vitamin deficiencies [16,17], renal dysfunction and hypothyroidism [18].

The results of enzymatic activities revealed significantly lower PON1 and arylesterase levels in oxytocin injected buffaloes as compared to control [14,19-21] also found a lower PON1 activity in the pregnant, early lactating and late lactating dairy cows. It might be correlated with increased level of homocysteine that triggered the atherosclerosis process due to which expression of PON1 gene in the hepatic tissue was down regulated [22,23]. It could be speculated that proatherogenic effects of tHcy might be involved in the reduction of serum PON1 activity and thus altered antioxidant function. The PON1 enzyme is responsible for both paraoxonase and arylesterase activities in bovine serum, because it hydrolyses organophosphates (such as paraoxon) and aromatic esters such as phenyl acetate $[24,25]$. Moreover, the elevated oxidative stress in the form of free radicals in the present study could lower PON1 activity [14,19]; whereas, increased lipid metabolism in the form of lipid peroxidation might also result in lower PON1 activity [21]. The lipids act as substrate for 
Table 1 Oxidative stress parameters (Mean \pm SE) of control and treated (oxytocin injected) lactating Bubalis bubalis (Nili Ravi) during different months of

\section{lactation}

\begin{tabular}{|c|c|c|c|c|c|c|c|c|c|c|c|c|}
\hline \multirow{2}{*}{ Parameters } & \multicolumn{2}{|c|}{ 1st month } & \multicolumn{2}{|c|}{ 2nd month } & \multicolumn{2}{|c|}{ 3rd month } & \multicolumn{2}{|c|}{ 4th month } & \multicolumn{2}{|c|}{ 5th month } & \multicolumn{2}{|c|}{ 6th month } \\
\hline & c & $\mathrm{T}$ & c & $\mathrm{T}$ & c & $\mathrm{T}$ & c & $\mathrm{T}$ & c & $\mathrm{T}$ & c & $\mathrm{T}$ \\
\hline TOS $(\mu \mathrm{Mol} / \mathrm{L})$ & $0.47 \pm 0.02^{c}$ & $0.97 \pm 0.08^{\mathrm{ab}}$ & $0.79 \pm 0.09^{b}$ & $0.79 \pm 0.09^{b}$ & $1.10 \pm 0.07^{a}$ & $1.12 \pm 0.08^{\mathrm{a}}$ & $1.08 \pm 0.06^{\mathrm{a}}$ & $1.00 \pm 0.05^{\mathrm{ab}}$ & $0.36 \pm 0.03^{c}$ & $0.98 \pm 0.071^{\mathrm{ab}}$ & $0.78 \pm 0.09^{b}$ & $0.97 \pm 0.06^{\mathrm{ab}}$ \\
\hline TAC (mMol/L) & $0.30 \pm 0.01^{\mathrm{efg}}$ & $0.20 \pm 0.02^{f g}$ & $0.40 \pm 0.06^{\mathrm{de}}$ & $0.26 \pm 0.02^{f g}$ & $1.06 \pm 0.02^{\mathrm{a}}$ & $0.49 \pm 0.06^{c d}$ & $0.78 \pm 0.03^{b}$ & $0.32 \pm 0.02^{\mathrm{ef}}$ & $0.18 \pm 0.02^{g}$ & $0.28 \pm 0.02^{e f g}$ & $0.55 \pm 0.08^{c}$ & $0.25 \pm 0.01^{\mathrm{fg}}$ \\
\hline tHcy $(\mu \mathrm{Mol} / \mathrm{L})$ & $12.72 \pm 0.59^{c d}$ & $16.77 \pm 0.99^{\mathrm{a}}$ & $10.43 \pm 0.30^{d}$ & $17.04 \pm 0.84^{\mathrm{a}}$ & $14.20 \pm 0.65^{\mathrm{bc}}$ & $15.77 \pm 0.66^{\mathrm{ab}}$ & $12.15 \pm 0.86^{\mathrm{cd}}$ & $17.52 \pm 0.57^{\mathrm{a}}$ & $14.03 \pm 0.92^{\mathrm{bc}}$ & $16.52 \pm 0.56^{\mathrm{ab}}$ & $15.32 \pm 0.33^{\mathrm{ab}}$ & $17.44 \pm 0.52^{\mathrm{a}}$ \\
\hline PON1 activity (U/L) & $35.06 \pm 2.68^{9}$ & $45.74 \pm 2.63^{\mathrm{bcd}}$ & $58.29 \pm 2.41^{\mathrm{a}}$ & $48.71 \pm 1.92^{b c}$ & $50.41 \pm 1.63^{\mathrm{bc}}$ & $45.59 \pm 2.22^{\text {bcde }}$ & $51.41 \pm 2.66^{\mathrm{ab}}$ & $40.59 \pm 1.33^{\text {defg }}$ & $46.98 \pm 1.12^{\mathrm{bcd}}$ & $38.51 \pm 1.46^{\mathrm{efg}}$ & $43.75 \pm 1.23^{\text {cdef }}$ & $37.64 \pm 0.86^{\mathrm{fg}}$ \\
\hline Arylesterase activity (U/L) & $47.12 \pm 1.45^{\mathrm{ab}}$ & $32.94 \pm 1.04^{f}$ & $32.98 \pm 1.38^{\mathrm{ef}}$ & $28.09 \pm 1.40^{f}$ & $43.94 \pm 1.59^{\mathrm{bc}}$ & $45.08 \pm 1.75^{b c}$ & $38.29 \pm 0.80^{\mathrm{de}}$ & $43.44 \pm 2.11^{\mathrm{bcd}}$ & $40.74 \pm 1.35^{c d}$ & $30.16 \pm 1.35^{f}$ & $52.06 \pm 0.74^{a}$ & $32.86 \pm 1.77^{f}$ \\
\hline $\begin{array}{l}\text { Ceruloplasmin oxidase } \\
\text { activity (U/L) }\end{array}$ & $32.06 \pm 2.35^{\mathrm{e}}$ & $55.91 \pm 5.71^{\mathrm{bcd}}$ & $45.31 \pm 2.87^{\mathrm{de}}$ & $33.09 \pm 1.82^{\mathrm{e}}$ & $51.63 \pm 2.09^{c d}$ & $50.73 \pm 3.80^{d}$ & $56.17 \pm 4.07^{\mathrm{bcd}}$ & $100.44 \pm 5.54^{\mathrm{a}}$ & $69.94 \pm 4.59^{b}$ & $65.20 \pm 4.55^{\mathrm{bc}}$ & $65.31 \pm 4.68^{\mathrm{bc}}$ & $58.16 \pm 1.74^{\mathrm{bcd}}$ \\
\hline
\end{tabular}

activity (U/L)

Values with different alphabets in a row significantly differ at $(P \leq 0.05)$.

Standard abbreviations and units are given in parenthesis.

" $\mathrm{C}$ " = Control group; " $\mathrm{T}$ " = Treatment group (oxytocin injected).

"TOS" = Total oxidant status; "TAC" = Total antioxidant capacity.

"tHcy" = Total homocysteine; "PON1" = paraoxonase-1. 
Table 2 Correlation coefficients of oxidative stress parameters in control lactating (Nili Ravi) buffaloes

\begin{tabular}{lllll}
\hline Parameters & Total oxidant status & Total antioxidant capacity & Arylesterase activity & Ceruloplasmin oxidase activity \\
\hline Total oxidant status $(\boldsymbol{\mu M o l} / \mathbf{L})$ & & 0.604 & & \\
& & $(0.000)$ & & \\
Total homocysteine $(\boldsymbol{\mu M o l} / \mathbf{L})$ & 0.481 & 0.389 & & 0.184 \\
& $(0.000)$ & $(0.002)$ & -0.379 & $(0.044)$ \\
Paraoxonase 1 activity (U/L) & 0.211 & 0.209 & $(0.000)$ & \\
& $(0.020)$ & $(0.022)$ & & \\
\hline
\end{tabular}

Values in parenthesis indicate significance $(P \leq 0.05)$.

Standard abbreviations and units are given in parenthesis.

Blank cells indicate non-significant correlation at $\mathrm{P} \geq 0.05$.

lipid peroxidation and an inverse relationship exists between lipid peroxidation and PON1 activity [26]. Additionally, inflammatory conditions induced by oxytocin injection could also be responsible for elevated oxidative stress, which directly decreased the PON1 activity [27].

Ceruloplasmin oxidase activity was found significantly higher in oxytocin injected buffaloes as compared to control. Ceruloplasmin has oxidase activity and is related with the host acute phase responses [28] and antioxidant defense in cattle $[29,30]$ so, its level might be enhanced during inflammation, tissue insult, certain malignant tumors [31,32] and oxidative stress to quench the free radicals, produced during oxidative stress. So, ceruloplasmin oxidase activity is the important health parameter that could be used to judge the health status and well-being of the animals [33]. Previous studies reported that higher ceruloplasmin oxidase activity in freshly calved animals is linked with a physiological phenomenon [34-36]. In the present study, increased activity of ceruloplasmin might be due to pathological inflammatory condition, induced by oxytocin [27]. In inflammatory conditions, cytokines such as interleukin-1 and interleukin- 6 are released from leukocytes which stimulate the liver to secrete ceruloplasmin [37].

\section{Conclusions}

In conclusion, oxytocin injection in lactating animals resulted in higher oxidative stress by enhancing the total homocysteine level and ceruloplasmin oxidase activity and decreasing enzymatic activities of antioxidant enzymes including paraoxonase- 1 and arylesterase. The results of present study discourage the irrational use of oxytocin for milk let down in lactating animals that may prone the animals to poor productive performance and reproductive efficiency.

\section{Methods}

\section{Experimental design}

Healthy, 4-7 years old freshly calved lactating (Nili Ravi) buffaloes $(n=40)$ were randomly selected and maintained on a commercial dairy farm located in the peri- urban area of district Faisalabad, Pakistan. The animals were allocated into two equal groups $(n=20$, each) viz. treatment (oxytocin injected) and control (without oxytocin injection) groups.

Both the groups were assigned to 4 replicates, 5 animals each. All the animals were milked twice a day (4.00 am and $4.00 \mathrm{pm}$ ), by injecting $3 \mathrm{ml}$ of oxytocin (10 IU/mL; Star Laboratories, Pakistan) 3-5 minutes before each milking.

Blood sampling was started exactly from day 15th post delivery that continued for a period of six months with an interval of 15 days between two successive samplings. Blood samples were collected from jugular vein using BD-vacutainer and sera samples were separated in eppendorf tubes from collected blood samples at 1107 $\times \mathrm{g}$ for 15 minutes and stored at $-20^{\circ} \mathrm{C}$ till analysis. All animal care and experimental procedures were carried out in accordance with the guide for the humane use and care of animals, approved by the animal care committee of University of Agriculture-Faisalabad, Pakistan.

\section{Determination of oxidative stress \\ Measurement of total oxidant status (TOS)}

The TOS of the body was estimated using the method, developed by [38]. Briefly, $35 \mu \mathrm{l}$ of serum samples were mixed with $225 \mu \mathrm{L}$ of reagent $1(150 \mu \mathrm{M}$ xylenol orange, $140 \mathrm{mM} \mathrm{NaCl}$ and $1.35 \mathrm{M}$ glycerol having a total volume of $1000 \mathrm{ml} ; \mathrm{pH}, 1.75)$. After mixing, the first absorbance was read. Then, $11 \mu \mathrm{L}$ of reagent $2(5 \mathrm{mM}$ ferrous ammonium sulfate and $10 \mathrm{mM} \mathrm{O}$-dianisidine dihydrochloride) was mixed with the solution containing reagent 1 and the serum sample. The final absorbance was read after $4 \mathrm{mi}-$ nutes after mixing with reagent 2 at bichromatic wavelengths, using a main wavelength of $560 \mathrm{~nm}$ and secondary/differential wavelength of $800 \mathrm{~nm}$. Then the TOS concentrations were calculated in terms of micromolar per liter of hydrogen peroxide.

\section{Measurement of total antioxidant capacity (TAC)}

The total antioxidant capacity of the body was determined by using a novel automated ABTS radical cation 
method [39]. Briefly, $5 \mu$ of serum samples were mixed with $200 \mu \mathrm{l}$ of reagent $1(0.4 \mathrm{M} / \mathrm{L}$ sodium acetate and $0.4 \mathrm{M} / \mathrm{L}$ glacial acetic acid; $\mathrm{pH}$ 5.8). Then $20 \mu \mathrm{l}$ of reagent $2(30 \mathrm{mM} / \mathrm{L}$ acetate buffer solution, $2 \mathrm{mM} / \mathrm{L} \mathrm{H} 2 \mathrm{O} 2$ and $10 \mathrm{mM} / \mathrm{L}$ 2,2'-azinobis 3-ethylbenzothiazoline-6-sulfonate; ABTS) was added to this mixture and reading was taken after 5 minutes of incubation at $37^{\circ} \mathrm{C}$. This absorbance was used to determine the TAC in terms of milimolar per liter of Trolox (Sigma, Vit. E analogue).

\section{Total homocysteine}

The quantitative determination of total L-homocysteine in the serum was determined by using the commercially available kit (The Diazyme Homocysteine Enzymatic Assay Kit; Ref. \# DZ 568A-K; Diazyme Laboratories, Gregg Court Poway, CA 92,064, USA).

\section{Determination of enzymatic activities Paraoxonase-1(PON1) activity}

The PON1 activity was determined by the hydrolysis of paraoxone into p-nitrophenol as described by [40]. Briefly, $10 \mu \mathrm{L}$ of serum sample was mixed with $350 \mu \mathrm{L}$ of paraoxonase substrate reagent $0.1 \mathrm{M}$ Tris- $\mathrm{HCl}$ buffer of pH 8.0, $2 \mathrm{mM}$ paraoxone (Sigma-Aldrich Laborchemi Kalien GmbHD-30,918, Seelze, Germany) as substrate and $2 \mathrm{mM} \mathrm{CaCl}_{2}$ without $\mathrm{NaCl}$ stimulation. The generation of p-nitrophenol was monitored at $405 \mathrm{~nm}$ on spectrophotometer Biosystem, BTS-330 (Biosystems, S. A. Costa Brava, Barcelona, Spain). The PON1 activity in terms of international units (U/L) was calculated by using the formula; [PON1 activity $(\mathrm{U} / \mathrm{L})=($ Absorbance/ $0.017) \times 50$ ]

Wheres, $50=$ dilution factor

$0.017=$ Micromolar absorptivity of the p-nitrophenol.

\section{Arylesterase activity}

Arylesterase activity was measured in term of phenylacetate hydrolysis as described by [41]. The reaction mixture contained $350 \mu \mathrm{L}$ of arylesterase substrate (2.0 mM phenylacetate, $2 \mathrm{mM} \mathrm{CaCl}_{2}$ in $0.1 \mathrm{M}$ Tris- $\mathrm{HCl}$ buffer of $\mathrm{pH} 8.0$ ) and $10 \mu \mathrm{L}$ of serum. The initial rate of hydrolysis was determined following the increase in arylesterase activity at $270 \mathrm{~nm}$ (Biosystem, BTS-330). The enzyme activity (U/L) was calculated by using the same formula as mentioned for PON1 Activity.

\section{Ceruloplasmin oxidase activity}

The enzymatic activity of ceruloplasmin oxidase was measured by using the slightly modified colorimetric method of [42]. Briefly, $750 \mu \mathrm{l}$ of acetate buffer (pH 5) was mixed with $50 \mu \mathrm{l}$ of the serum sample and incubated at $30^{\circ} \mathrm{C}$ (water bath) in duplicate test tubes for 5 minutes. Then $200 \mu \mathrm{l}$ of substrate $(250 \mathrm{mg}$ of orthodianisidine dihydrochloride (Sigma) was brought upto
$100 \mathrm{ml}$ with deionized water), was added to both the test tubes. After 5 and 15 minutes of substrate addition, $2 \mathrm{ml}$ of sulfuric acid $(9 \mathrm{M})$ was added to stop the reaction. The absorbance of both the test tubes was taken at $540 \mathrm{~nm}$ wavelength by using a UV/Vis spectrophotometer (Hitachi U-2001, USA). Then following formula was used to calculate the enzymatic activity.

Ceruloplasmin oxidase activity $(\mathrm{U} / \mathrm{L})=\mathrm{Abs}_{15 \min }-\mathrm{Abs}_{5 \min } \times 6.25 \times 10^{2}$

Whereas,

$\mathrm{Abs}_{15 \min }$ and $\mathrm{Abs}_{5 \min }$ were the absorbance of samples after 15 and 5 minutes respectively. $6.25 \times 10^{2}$ was the dilution factor of the reaction mixture.

\section{Statistical analysis}

Data were analyzed statistically using two way analysis of variance, whereas, the means for significance between different groups was detected by using Duncan Multiple Range Test (DMR). All the values were considered significant at $\mathrm{P} \leq 0.05$.

\section{Competing interests}

The authors declare that they have no competing interests.

\section{Authors' contributions}

ZI and ZUR designed and conducted the study. ZI and MMA wrote the manuscript and analyzed the data. HA, and SS performed the analysis. FM and TK helped to write the manuscript. All authors have read and approved the final manuscript.

\section{Acknowledgements}

The authors are grateful to the Chair of the Department of Physiology and Pharmacology, University of Agriculture, Faisalabad, Pakistan for providing the technical facilities to accomplish this research project.

\section{Author details}

${ }^{1}$ Department of Basic Sciences, sub campus Jhang, University of Veterinary and Animal Sciences, Lahore, Pakistan. ${ }^{2}$ Sub-Campus Toba Tek Singh, University of Agriculture, Faisalabad, Pakistan. ${ }^{3}$ Department of Physiology and Pharmacology, University of Agriculture, Faisalabad, Pakistan. ${ }^{4}$ Department of Physiology, GC University, Faisalabad, Pakistan. ${ }^{5}$ Department of Pathobiology, sub campus Jhang, University of Veterinary and Animal Sciences, Lahore, Pakistan. ${ }^{6}$ Government College of Home Economics, Lahore, Pakistan.

Received: 18 April 2013 Accepted: 22 August 2013

Published: 27 August 2013

\section{References}

1. Hoberg MS, Lind O: Milking the buffalo: chapter 6 in buffalo milk production; 2003. www.milkproduction.com (Accessed date 10/2/2013).

2. Macuhova J, Tancin V, Bruckmaier RM: Effects of oxytocin administration on oxytocin release and milk ejection. J Dairy Sci 2004, 87:1236-1244.

3. Thomas CS, Bruckmairer RM, Ostensson K, Svennersten-Sjaunja K: Effect of different milking routines on milking-related release of the hormones oxytocin, prolactin and cortisole and on milk yield and milking performance in Murrah Buffaloes. J Dairy Sci 2005, 72:10-18.

4. Bruckmaier RM: Chronic oxytocin treatment causes reduced milk ejection in dairy cows. J Dairy Sci 2003, 70:123-126.

5. Ghiselli A, Serafini M, Natella F, Scaccini C: Total antioxidant capacity as a tool to assess redox status: critical view and experimental data. Free Radical Biol Med 2000, 29:1106-1114.

6. Castillo C, Hernandez J, Lopez-Alonso M, Miranda M, Benedito JL: Values of plasma lipid hydroperoxides and total antioxidant status in healthy dairy cows: Preliminary observations. Arch Anim Breed 2003, 46:227-233. 
7. Roth E: Oxygen free radicals and their clinical implications. Acta Chir Hung 2000, 36:302-305.

8. Castillo C, Hernandez J, Bravo A, Lopez-Alonso M, Pereira V, Benedito JL: Oxidative status during late pregnancy and early lactation in dairy cows. Vet J 2005, 169:286-292.

9. Goff JP, Horst RL: Physiological changes at parturition and their relationship to metabolic disorders. J Dairy Sci 1997, 80:1260-1268.

10. Piccione G, Casella S, Assenza A, Fazio F, Caola G: Evaluation of serum homocysteine and oxidative stress during lactation in ewes. Czech J Anim Sci 2008, 53(Suppl 11):462-465.

11. Hanif $K$, Lederis $K$, Hollenberg MO: Inability of oxytocin to activate pyruvate dehydrogenase in the Brattleboro rat. Science 1982, 216:1010.

12. Mudron P, Rehage J, Qualmann K, Sallman HP, Scholz H: A study of lipid peroxidation and vitamin $\mathrm{E}$ in dairy cows with hepatic insufficiency. J Vet Med part A 1999, 46:219-224

13. Wachter CM, McDaniel BT, Whitlow LW, Pettyjohn S: Genetics of antioxidant activity in Holsteins and Jerseys: Associations with various traits. J Dairy Sci 1999, 82(Suppl.1):31.

14. Turk R, Juretic D, Geres D, Turk N, Rekic B, Simeon-Rudolf V, Svetina A: Serum paraoxonase activity in dairy cows during pregnancy. Res Vet Sci 2005, 79:15-18.

15. Bernabucci U, Ronchi B, Lacetera N, Nardone A: Influence of body condition score on relationships between metabolic status and oxidative stress in periparturient dairy cows. J Dairy Sci 2005, 88:2017-2026.

16. Yeh YY, Yeh SM: Homocysteine-lowering action is another potential cardiovascular protective factor of aged garlic extract. J Nutr 2006, 136:745-749.

17. Kalantar-Zadeh K, Ikizler TA, Block G, Avram MM, Kopple JD: Malnutritioninflammation complex syndrome in dialysis patients: causes and consequences. Am J Kidney Dis 2003, 42:864-881.

18. Liaugudas $G$, Jacques PF, Selhub J, Rosebeng $\mathbb{H}$, Bostom AG: Renal insufficiency, vitamin $B(12)$ status and population attritubale risk for mild hyperhomocysteinemia among coronary artery disease patients in the era of folic acid-fortified cereal grain flour. Arteriosd Thromb Vasc Biol 2001, 21:849-851.

19. Turk R, Juretic D, Geres D, Turk N, Rekic B, Simeon-Rudolf V, Svetina A: Serum paraxonase activity and lipid parameters in the early postpartum period of dairy cows. Res Vet Sci 2004, 76:57-61.

20. Turk R, Juretic D, Geres D, Turk N, Rekic B, Simeon-Rudolf V, Svetina A: Oxidative stress in dairy cows-serum paraoxonase activity related to hepatomegaly. Croat Chem Acta 2005, 78:375-378.

21. Turk R, Juretic D, Geres D, Sventina A, Turk N, Flegar-Mestric Z: Influence of oxidative stress and metabolic adaptation on PON1 activity and MDA level in transition dairy cows. Anim Reprod Sci 2008, 108:98-106.

22. Wang $H$, Yang $X$, Yang F, Gaubatz JW, Ma L, Magera MJ, Yang X, Berger PB, Durante W, Pownall HJ, Schafer Al: Hyperhomocysteinemia accelerates atherosclerosis in cystathionine beta-synthase and apoliproprotein $\mathrm{E}$ double knock out mice with or without dietary perturbation. Blood 2003, 101:3901-3907.

23. Janel N, Robert K, Chabert C, Ledru A, Gouedard C, Barouki R: Mouse liver paraoxonase-1 gene expression is down regulated in hyperhomocysteinemia. Thromb Haemost 2004, 92:221-222.

24. Miyamoto T, Takahashi Y, Oohashi T, Sato K, Oikawa S: Bovine paraoxonase 1 activities in serum and distribution in lipoproteins. J Vet Med Sci 2005, 67:243-248

25. Aviram M, Rosenblat M, Bisgaier CL, Newton RS, Primo-Parmo SL, La Du BN: Paraoxonase inhibits high-density lipoprotein oxidation and preserves its function: a possible peroxidative role for paraoxonase. J Clin Invest 1998, 101:1581-1590.

26. Aviram M, Rosenblat M: Paraoxonases 1, 2, and 3, oxidative stress and macrophage foam cell formation during atherosclerosis development. Free Radic Biol Med 2004, 9:1304-1316.

27. Bionaz M, Trevisi E, Calamari L, Librandi F, Ferrai A, Bertoni G: Plasma paraoxonase, health, inflammatory conditions and liver function in transition dairy cows. J Dairy Sci 2007, 90:1740-1750.

28. Denko CW: Protective role of ceruloplasmin in inflammation. Agents Actions 1979, 9:333-339.

29. Goldstein IM, Kaplan HB, Edelson HS, Weissman G: Ceruloplasmin: a scavenger of superoxide anion radicals. J Biol Chem 1979, 254:4040-4045.

30. Sheldon IM, Noakes DE, Rycroft AN, Dobson H: Acute phase protein responses to uterine bacterial contamination in cattle after calving. Vet Rec 2001, 148:172-175.
31. Cousins RJ: Absorption, transport and heapatic metabolism of copper and zinc. Physiol Rev 1985, 65:238-309.

32. Szczubiał M, Dąbroweski R, Kankofer M, Bochniarz M, Albera E: Concentration of serum amyloid A and activity of ceruloplasmin in milk from cows with clinical and subclinical mastitis. Bull Vet Inst Pulawy 2008, 52:391-395.

33. Skinner JG: Special report international standardization of acute phase proteins. Vet Clin Pathol 2001, 30:2-7.

34. Blakley B, Hamilton D: Ceruloplasmin as an indicator of copper status in cattle and sheep. Can J Comp Med 1985, 49:405-408.

35. Koets A, Schartz DN, Tooten P: Release of proinflammatory cytokines related to luteolysis and the periparturient acute phase response in prostaglandininduced parturition in cows. Theriogenology 1998, 49:797-812.

36. Hussein AH, Staufenbiel R, Müller AE, El-Sebaie A, Abd-El-Salam M: Ceruloplasmin activity in Holstein dairy cows: effects of lactation stages and anticoagulants. Comp Clin Pathol 2012, 21:705-710.

37. Gruys E, Toussaint MJM, Landman WJM, Tivapasi M, Chamanza R, Van Veen $\mathrm{L}$ : Infection, inflammation and stress inhibit growth: mechanisms and non-specific assessment of the processes by acute phase proteins. In Production diseases in farm animals. Edited by Wensing T. Wageningen, The Netherlands: Wageningen Press; 1998:72-87.

38. Erel $\mathrm{O}$ : A new automated colorimetric method for measuring total oxidant status. Clin Biochem 2005, 38:1103-1111.

39. Erel O: A novel automated direct measurement method for total antioxidant capacity using a new generation, more stable ABTS radical cation. Clin Biochem 2004, 37:277-285.

40. Mackness MI, Harty D, Bhatnagar D, Wincour PH, Arrol S, Ishola M, Durrington PN: Serum paraoxonase activity in familial hypercholesterolaemia and insulin-dependant diabetes mellitus. Atherosd 1991, 86:193-199.

41. Juretic D, Motejlkova A, Kunovic B, Rekic B, Mestric ZF, Vujic L, Mesic R, Bajalo JL, Rudolf VS: Paraoxonase/arylesterase in serum of patients with type II diabetes mellitus. Acta Pharm 2006, 56:59-68.

42. Schosinsky KH, Lehmann HP, Beeler MF: Measurement of ceruloplasmin from its oxidase activity in serum by use of $o$-dianisidine dihydrochloride. Clin Chem 1974, 20(Suppl 12):1556-1563.

doi:10.1186/1746-6148-9-169

Cite this article as: lqbal et al.: Oxytocin induced oxidative stress in lactating Bubalis bubalis (Nili Ravi). BMC Veterinary Research 2013 9:169.

\section{Submit your next manuscript to BioMed Central and take full advantage of:}

- Convenient online submission

- Thorough peer review

- No space constraints or color figure charges

- Immediate publication on acceptance

- Inclusion in PubMed, CAS, Scopus and Google Scholar

- Research which is freely available for redistribution 